\title{
ANALISIS KEMITRAAN ANTARA PABRIK GULA JATITUJUH DENGAN PETANI TEBU RAKYAT DI MAJALENGKA, JAWA BARAT
}

\section{Patnership Analysis between Jatitujuh Sugar Factory with Sugarcane Factory in Majalengka, West Java}

\author{
Ratna Fadilah*) dan Sumardjo
}

Departemen Sains Komunikasi dan Pengembangan Masyarakat, Fakultas Ekologi Manusia, IPB

*) E-mail : ratna_fad@gmail.com

Diterima 22 Oktober 2010/Disetujui 12 April 2011

\begin{abstract}
The aim of this research was to know the implementation of a partnership between sugar mill and sugar cane farmer folk and its relationship to the effectiveness of partnership and community empowerment. This research was conducted in PG Jatitujuh, Majalengka, Province of West Java. Research approach designed by survey, the research respondents were 46 farmer group chairmen. The research uses quantitative and qualitative statistical method with Rank Spearman Correlation to examine variables. Results showed that the partnership helps in empowering the community and increasing the effectiveness of the partnership.
\end{abstract}

Keywords: partnership, effectiveness, community empowerment

\section{PENDAHULUAN}

\section{Latar Belakang}

Pada tahun 1984-1985 Indonesia pernah menjadi negara swasembada gula. Swasembada gula yang diraih Indonesia memang tidak dapat dipertahankan. Meningkatnya jumlah penduduk di Indonesia, krisis keuangan, dan penyebab-penyebab lainnya membuat Indonesia kembali menjadi negara pengimpor gula. Selain itu, peningkatan jumlah produksi juga tidak bisa mengimbangi peningkatan jumlah kebutuhan gula bagi masyarakat Indonesia. Selisih yang jauh antara kebutuhan gula dan produksi gula membuat Indonesia menjadi negara ketiga di dunia yang paling banyak mengimpor gula, setelah Rusia dan India. Oleh karena itu, pemerintah Indonesia mengharapkan bisa mencapai swasembada gula pada tahun 2014. Swasembada gula 2014 direncanakan untuk memenuhi kebutuhan rumah tangga serta industri makanan dan minuman di Indonesia.

Salah satu cara yang dilakukan oleh pemerintah untuk mencapai swasembada gula 2014 adalah dengan membangkitkan kembali semangat para petani tebu. Cara yang dilakukan pemerintah untuk lebih meningkatkan minat para petani tebu serta mengamankan kebutuhan tebu adalah dengan melancarkan program TRI (Tebu Rakyat Intensifikasi) (Ikatan Ahli Gula Indonesia, 1975). Program ini juga bertujuan untuk meningkatkan produktivitas areal tanam. Pemerintah bekerja sama dengan bank untuk memberikan paket kredit yang terdiri atas bibit tebu, pupuk pestisida, biaya tebang dan angkut, serta kredit untuk menunjang biaya hidup dengan bunga yang rendah dalam pelaksanaan program TRI.

Pabrik Gula (PG) Jatitujuh merupakan salah satu pabrik gula terbesar yang ada di Jawa Barat (PG Jatitujuh, 2007). Dalam memenuhi kebutuhan tebu untuk produksi, PG Jatitujuh melakukan kemitraan dengan para petani tebu rakyat. Sebelumnya PG Jatitujuh hanya mengolah tebu dari lahan HGU (Hak Guna Usaha) sendiri, namun sejak tahun 2004, PG Jatitujuh juga menerima pasokan tebu rakyat guna meningkatnya produksi gula mereka.

Petani tebu rakyat yang bermitra dengan PG Jatitujuh untuk mendapakan bantuan kredit harus membentuk kelompok tani. Hal ini dilakukan guna mempermudah proses pemberian kredit agar berjalan secara efisien. Ada kecenderungan jumlah kelompok tani yang bermitra dengan PG Jatitujuh semakin banyak. Hal ini dapat menjadi indikator bahwa para petani tebu tertarik untuk melakukan kemitraan dengan PG Jatitujuh. Oleh karena itu, menarik untuk mengetahui tentang pelaksanaan kemitraan antara PG Jatitujuh dengan petani tebu rakyat.

\section{Rumusan Masalah}

1. Sejauh mana pelaksanaan kemitraan antara PG Jatitujuh dengan petani tebu rakyat?

2. Sejauh mana intensitas kemitraan berkaitan dengan keberdayaan masyarakat, khususnya petani tebu?

3. Bagaimana hubungan intensitas kemitraan dan keberdayaan masyarakat dengan efektivitas kemitraan? 


\section{Tujuan Penelitian}

1. Menganalisis pelaksanaan kemitraan antara PG Jatitujuh dengan petani tebu rakyat.

2. Menganalisis intensitas kemitraan berkaitan dengan keberdayaan masyarakat, khususnya petani tebu.

3. Menganalisis hubungan intensitas kemitraan dan keberdayaan masyarakat dengan efektivitas kemitraan.

\section{Kegunaan Penelitian}

Adanya penelitian ini, diharapkan masyarakat dapat memperoleh gambaran mengenai pelaksanaan kemitraan antara petani tebu rakyat dan pabrik gula. Bagi civitas akademik lainnya, tulisan ini dapat menjadi bahan acuan untuk penelitian lain mengenai kemitraan antara petani tebu rakyat dan pabrik gula. Penelitian ini juga diharapkan dapat memberikan gambaran dan masukan bagi pabrik gula mengenai pelaksanaan kemitraan dengan petani tebu rakyat. Bagi peneliti, penelitian ini dapat menjadi sarana dalam menerapkan ilmu yang telah didapat selama kuliah dan menambah pengetahuan mengenai pelaksanaan kemitraan.

\section{PENDEKATAN TEORITIS}

\section{Tinjauan Pustaka}

\section{Permasalahan Petani Tebu Rakyat}

Petani tebu rakyat adalah seseorang yang menanam tanaman tebu di lahan sendiri dengan modal sendiri atau pinjaman. Permodalan merupakan salah satu faktor kunci dalam industri gula. Bagi petani tebu rakyat permodalan bisa bersumber dari modal sendiri atau pinjaman. Namun petani lebih banyak mengandalkan pinjaman dari pelepas uang atau kredit karena biaya permodalan dalam usaha tani tebu cukup tinggi.

Saat Indonesia merdeka, tebu rakyat berkembang dengan sendirinya tanpa ada campur tangan dari pemerintah. Namun, perkembangan kembali tebu rakyat juga mengalami kendala. Modal yang cukup tinggi dibutuhkan dalam penanaman tebu rakyat. Petani pun cukup kesulitan untuk memperoleh modal. Akhirnya para petani tebu berinisiatif membentuk Yatra (Yayasan Tebu Rakyat). Para petani tebu menghimpun dana dari berbagai pihak termasuk dari petani tebu sendiri. Berkat bantuan Yatra, petani tebu kembali dapat bertani sehingga luas areal tebu rakyat meningkat. Melihat peningkatan tersebut, pabrik gula pun tertarik untuk memberikan kredit kepada petani tebu agar harga beli tebu dapat lebih murah. Pabrik gula pun memberikan kredit dengan bunga yang lebih rendah daripada Yatra. Petani pun banyak yang beralih mengambil kredit dari pabrik gula.

Seiring dengan berkembangnya kembali tebu rakyat di Indonesia, Presiden Indonesia saat itu, Soekarno, memberikan petunjuk mengenai maksud dari penanaman tebu rakyat. Hal tersebut disampaikan dalam salah satu keputusan rapat Dewan Stabilisasi Ekonomi tanggal 18 Febuari 1975 (Ikatan Ahli Gula Indonesia,
1975). Petunjuk tentang maksud penanaman tebu rakyat, yaitu:

a. Untuk menghindarkan masalah sewa tanah yang selalu timbul setiap tahun,

b. Untuk menjamin kemantapan produksi gula,

c. Memperbaiki penghasilan petani di sekitar pabrik gula.

\section{Kemitraan dan Permasalahannya}

Definisi kemitraan menurut beberapa ahli, antara lain: menurut Hafsah (2000), kemitraan adalah suatu strategi bisnis yang dilakukan oleh dua pihak atau lebih dalam jangka waktu tertentu untuk meraih manfaat atau keuntungan bersama sesuai prinsip saling membutuhkan dan saling mengisi berdasarkan pada kesepakatan. Adapun menurut Partomo (2004), kemitraan usaha merupakan salah satu strategi pengembangan UKM di mana terdapat hubungan kerja sama usaha di antara pihak yang bersifat sinergis, suka rela, berdasarkan prinsip saling membutuhkan, saling mendukung, dan saling menguntungkan disertai dengan pembinaan dan pengembangan UKM oleh usaha besar. Konsep formal kemitraan terdapat dalam Undang-Undang Nomor 9 tahun 1995: "Kemitraan adalah kerja sama antara usaha kecil dengan usaha menengah atau dengan usaha besar yang disertai dengan pembinaan dan pengembangan usaha yang berkelanjutan oleh usaha besar atau usaha menengah dengan memperhatikan prinsip saling memerlukan, saling memperkuat, dan saling menguntungkan" (Sumardjo, 2004).

Maksud dan tujuan dari kemitraan adalah "win-win solution partnership", di mana kedua pihak yang bermitra tidak ada yang dirugikan, keduanya sama-sama mendapatkan keuntungan melalui praktik kemitraan (Hafsah, 2000). Kemitraan usaha menjamin kemandirian pihak-pihak yang bermitra karena kemitraan bukanlah proses merger atau akuisisi. Kemitraan juga bertujuan untuk meningkatkan pendapatan, menjaga kesinambungan usaha, meningkatkan kualitas sumber daya kelompok mitra, peningkatan skala usaha, mengurangi resiko usaha, meningkatkan efisiensi, meningkatkan daya saing usaha serta menumbuhkan dan meningkatkan kemampuan usaha kelompok usaha mandiri. Kemitraan diharapkan dapat memacu pertumbuhan ekonomi sekaligus mendorong pemerataan kesejahteraan, penyerapan tenaga kerja, pendapatan masyarakat, dan pertumbuhan ekonomi regional (wilayah).

\section{Jenis dan Pola Kemitraan}

Direktorat Pengembangan Usaha, Departemen Pertanian dalam Puspitawati (2006) memberikan panduan mengenai beberapa jenis pola kemitraan, yaitu:
a. Inti Plasma
b. Subkontrak
c. Perdagangan Umum
d. Keagenan
e. Kerja sama Operasional Khusus (KOA)
f. Pola Kemitraan Saham 


\section{Konsep Pemberdayaan Masyarakat}

Empowerment dalam Bahasa Indonesia berarti pemberdayaan. Konsep mengenai pemberdayaan lahir sebagai bagian dari perkembangan alam pikiran masyarakat dan kebudayaan Barat, terutama Eropa. Menurut Prijono (1996), dalam membahas dan memprogramkan konsep pemberdayaan, harus ditentukan terlebih dahulu sikap bersama mengenai maksud dan arti kekuasaan.

Pemberdayaan masyarakat dapat didefinisikan sebagai tindakan sosial di mana penduduk sebuah komunitas mengorganisasikan diri dalam membuat perencanaan dan tindakan kolektif untuk memecahkan masalah sosial atau memenuhi kebutuhan sosial sesuai dengan kemampuan dan sumber daya yang dimilikinya (Sumodiningrat, 2009). Pemberdayaan mengacu kepada kemampuan masyarakat untuk mendapatkan dan memanfaatkan akses dan kontrol terhadap sumber daya. Proses pemberdayaan masyarakat bertujuan untuk membantu memperoleh daya atau kuasa untuk mengambil keputusan dan menentukan tindakan yang akan diambil berkaitan dengan diri mereka sendiri. Pemberdayaan secara konseptual pada intinya membahas bagaimana individu, kelompok atau komunitas berusaha mengontrol kehidupan mereka sendiri dan mengusahakan untuk membentuk masa depan sesuai keinginan mereka (Nasdian, 2006).

\section{Peran Petani Tebu dan Pabrik Gula}

Kebutuhan gula di Indonesia semakin meningkat setiap tahun akibat peningkatan jumlah penduduk di Indonesia. Oleh karena itu, pilihan yang tepat bagi pabrik gula adalah bermitra dengan petani tebu rakyat. Bukan hanya hubungan dagang biasa dan bukan hubungan monopsoni, tetapi hubungan kerja sama yang bersifat timbal balik, saling menguntungkan antara pabrik gula dan petani tebu rakyat. Hafsah (2003) menyatakan bahwa khusus pabrik gula milik BUMN, dalam hubungan kemitraan dengan petani memberikan subsidi baik langsung maupun tidak langsung, misalnya subsidi harga bibit dari pabrik gula, biaya penelitian dan pengembangan, biaya pendahuluan bagi petani, atau biaya tebang angkut.

Hubungan petani tebu dengan pabrik gula perlu ditingkatkan melalui hubungan kemitraan subkontrak (Hafsah, 2003). Pabrik gula membutuhkan tebu yang dihasilkan oleh petani tebu rakyat untuk memenuhi pasokan bahan baku tebu. Sedangkan petani tebu membutuhkan permodalan yang cukup tinggi yang dapat diperoleh melalui kredit dengan pabrik gula. Kemitraan antara pabrik gula juga melibatkan bank sebagai pemilik modal. Pabrik gula hanya sebagai penyalur modal yang diberikan oleh bank.

Peranan lain pabrik gula di dalam kemitraan antara lain (Hafsah, 2003):

a. Melaksanakan alih pengetahuan dan keterampilan dalam meningkatkan kualitas SDM petani/koperasi, baik melalui pendidikan, pelatihan, dan magang dalam bidang kewirausahaan, manajemen, dan keterampilan teknis, b. Secara bersama menyusun rencana usahan dengan petani/koperasi mitranya untuk disepakati bersama,

c. Apabila perlu, pabrik gula bertindak sebagai penyandang dana atau penjamin kredit (avalis) untuk permodalan petani/koperasi mitranya,

d. Melaksanakan bimbingan teknologi kepada petani/koperasi,

e. Melaksanakan pelayanan dan penyediaan sarana produksi untuk keperluan usaha bersama yang disepakati,

f. Menjamin pembelian hasil produksi petani/koperasi sesuai dengan kesepakatan yang telah disusun bersama.

\section{Kerangka Pemikiran}

Indonesia pernah meraih swasembada gula pada tahun 1984 (Hafsah, 2003). Namun, hal itu tidak dapat dipertahankan akibat makin tingginya permintaan gula di Indonesia yang tidak bisa diimbangi dengan peningkatan produksi oleh pabrik gula. Pemerintah Indonesia merencanakan ingin meraih lagi gelar swasembada gula pada tahun 2014. Salah satu cara yang dilakukan pemerintah dalam rangka menuju swasembada gula adalah dengan merangkul kembali petani tebu yang telah beralih ke pertanian lain. Pemerintah menawarkan Program Tebu Rakyat Intensifikasi (TRI) kepada petani tebu untuk merangsang kembali minat untuk menanam tebu.

Kemitraan yang terjadi antara petani tebu rakyat dan pabrik gula, secara tidak langsung juga membantu dalam memberdayakan masyarakat di sekitar pabrik gula, khususnya para petani. Pelaksanaan kemitraan diduga berhubungan erat dengan efektivitas kemitraan yang diukur dengan aksesibilitas permodalan, kelancaran pemasaran hasil panen, tingkat modernisasi alat, tingkat kemampuan, kerapihan keuangan, dan tingkat keuntungan yang diperoleh petani. Variabel untuk mengukur efektivitas kemitraan didapat dari tujuan dan manfaat pelaksanaan kemitraan. Selain itu, keberdayaan masyarakat diduga mempengaruhi keberdayaan masyarakat. 


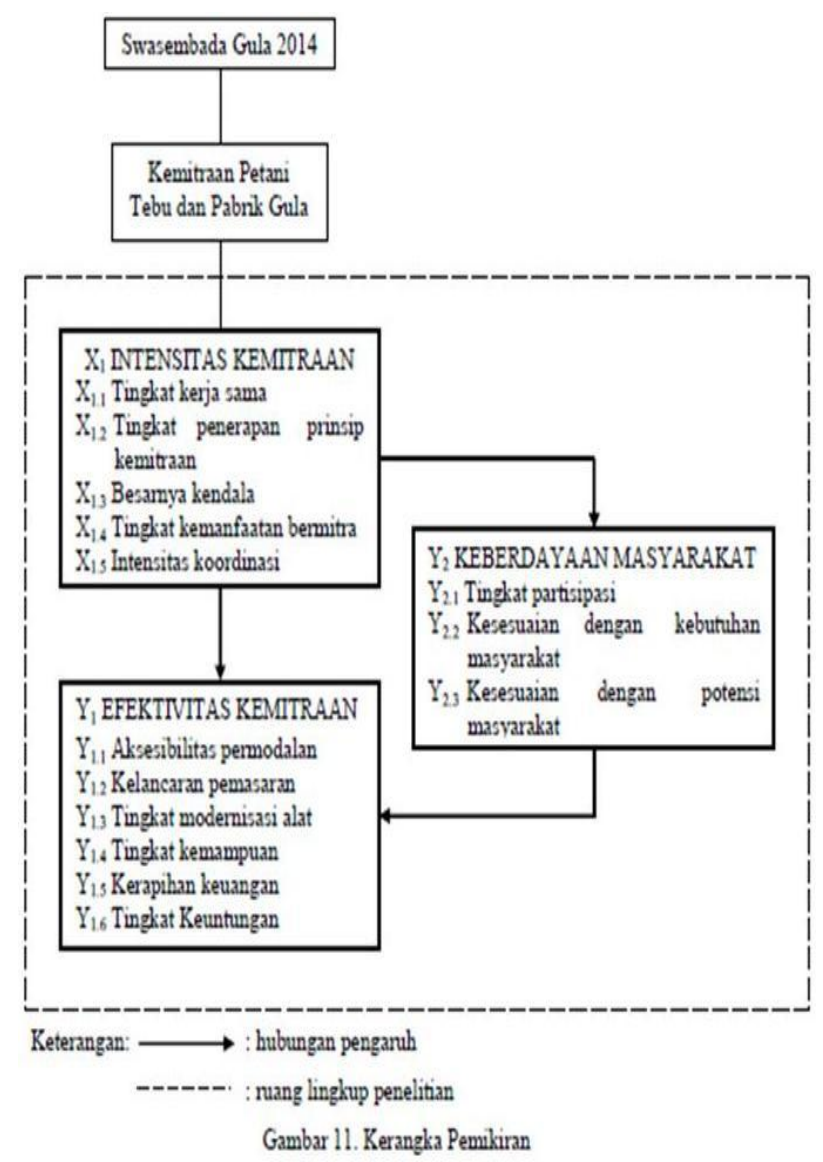

\section{Hipotesis Penelitian}

1. Terdapat hubungan nyata dan positif antara intensitas kemitraan dengan efektivitas kemitraan.

2. Terdapat hubungan nyata dan positif antara intensitas kemitraan dengan keberdayaan masyarakat.

3. Terdapat hubungan nyata dan positif antara keberdayaan masyarakat dengan efektivitas kemitraan.

\section{PENDEKATAN LAPANG}

\section{Metode Penelitian}

Jenis penelitian yang digunakan dalam penelitian ini adalah penelitian survei. Penelitian survei adalah penelitian yang mengambil sampel dari satu populasi dan menggunakan kuesioner sebagai alat pengumpul data yang pokok (Singarimbun, 1995). Penelitian ini menggunakan metode kuantitatif yang didukung oleh data kualitatif. Metode kuantitatif dilakukan dengan cara survei pengisian kuesioner oleh responden. Pengisian kuesioner oleh responden dilakukan dengan teknik wawancara langsung. Kuesioner diisi untuk mendapatkan data mengenai intensitas kemitraan, efektivitas kemitraan bagi petani tebu, dan keberdayaan yang didapat masyarakat dari kemitraan. Adapun data kualitatif digunakan untuk menggali informasi lebih dalam dan untuk mendukung dalam menginterpretasikan data kuantitatif.

\section{Lokasi dan Waktu}

Penelitian dilakukan di daerah perkebunan tebu milik PG Rajawali II, Unit PG Jatitujuh yang terletak di Desa Sumber, Kec. Jatitujuh, Kabupaten Majalengka, Propinsi Jawa Barat. Pemilihan lokasi dilakukan secara sengaja karena di desa tersebut terdapat kemitraan antara PG Jatitujuh dengan petani tebu rakyat. Penelitian dilakukan dari bulan Mei-Juni 2010.

\section{Teknik Pemilihan Responden dan Informan}

Responden yang diambil dalam penelitian ini adalah ketua kelompok tani yang mewakili anggotanya, juga dirinya sendiri, dalam memberikan informasi mengenai pelaksanaan kemitraan dengan PG Jatitujuh. Pemilihan responden dilakukan dengan teknik stratified random sampling (pengambilan sampel acak distratifikasi), yaitu membagi populasi ke dalam lapisan-lapisan (strata) yang seragam dan setiap lapisan dipilih sampel secara acak (Singarimbun, 1995). Populasi dibagi berdasarkan luas lahan tebu. Sampel diambil secara proposional dari tiap-tiap stratum, di mana unsur-unsur satuan yang diambil dari tiap stratum berbanding lurus dengan jumlah satuan elementer dalam stratum yang bersangkutan. Populasi dibagi tiga stratum berdasarkan luas lahan. Hal ini dilakukan agar terjadi pemerataan informasi yang didapat dari responden yang memiliki luas lahan berbeda.

Informan dalam penelitian ini adalah pihak PG Jatitujuh, Koperasi Manis Jaya dan DPC APTRI (Dewan Pimpinan Cabang Asosiasi Petani Tebu Rakyat Indonesia) PG Jatitujuh, Sinder Kepala Kebun, dan Sinder Kepala Wilayah. Informan diharapkan mampu memberikan informasi mengenai pelaksanaan kemitraan subkontrak. Jumlah informan yang dipilih dalam penelitian ini tidak dibatasi untuk menambah informasi dan gambaran yang lebih luas mengenai PG Jatitujuh dan pelaksanaan kemitraan pabrik gula dan petani tebu.

\section{Teknik Pengumpulan Data}

Jenis data yang dikumpulkan adalah data primer dan sekunder. Metode yang digunakan dalam pengambilan data adalah wawancara dan kuesioner. Data primer dalam penelitian ini didapat melalui pengisian kuesioner dan wawancara, sedangkan data sekunder didapat dari penelusuran dokumen, literatur atau laporan-laporan yang terkait dengan topik penelitian.

\section{Teknik Analisis Data}

Data kuantitatif yang dikumpulkan diolah dengan software SPSS 16.0 for Windows untuk menguji hubungan antar variabel. Data kemudian dianalisis dan diinterpretasikan menggunakan analisis deskriptif dan Uji Korelasi Rank Spearman. Uji Korelasi Ranks Spearman digunakan untuk menganalisis hubungan antara dua variabel dari skala pengukuran ordinal. Data kualitatif digunakan untuk menggali lebih dalam mengenai data yang telah diperoleh secara kuantitatif.

Bobot nilai pada setiap jawaban responden akan dihitung melalui transformasi masing masing variabel untuk mendapatkan nilai rataan. 


$$
\begin{aligned}
& \text { rumus transformasi skor tiap variabel= } \\
& \frac{\Sigma \text { skor }-\Sigma \text { skor minimum }}{\Sigma \text { max }-\Sigma \text { skor minimum }} \times 100 \%
\end{aligned}
$$

Setelah data ditransformasikan kemudian dilakukan penilaian dan dibagi menjadi beberapa kategori yakni sebagai berikut:

Tabel 1. Bobot Penilaian Skor Per Variabe1

\begin{tabular}{|c|c|}
\hline $\begin{array}{c}\text { Range (dalam } \\
\text { persen) }\end{array}$ & $\begin{array}{c}\text { Penilaian skor } \\
\text { per variabel }\end{array}$ \\
\hline $0-50$ & Rendah \\
\hline $51-75$ & Sedang \\
\hline $76-100$ & Tinggi \\
\hline
\end{tabular}

\section{GAMBARAN LOKASI UMUM PENELITIAN PT. PG JATITUJUH}

Unit usaha PG Jatitujuh berada di bawah PT. PG Rajawali II bersama dengan PG Subang, PG Tersana Baru, PG Karangsuwung, PG Sindanglaut, dan PSA (Pabrik Spirtus dan Alkohol) Palimanan. Sedangkan 3 pabrik gula lain yang sebelumnya dikelola juga oleh PTP XIV yaitu Gempol, Jatiwangi, dan Kadipaten terpaksa ditutup akibat permasalahan sulitnya pemasukan areal. Saat ini, di antara PG lain yang berada di bawah PT. PG Rajawali II, PG Jatitujuh merupakan pabrik gula yang memiliki kapasitas giling dan produksi gula terbesar. Pabrik Gula Jatitujuh juga merupakan pabrik gula dengan kapasitas terbesar di Jawa Barat.

\section{Areal dan Sarana Perusahaan}

PG Jatitujuh memiliki letak administratif di Desa Sumber, Kecamatan Jatitujuh, Kabupaten Majalengka. Arealnya berlokasi di dua kabupaten, yaitu Majalengka dan Indramayu. Areal yang berada di Kabupaten Majalengka memiliki luas 5673.04 Ha, sedangkan areal yang terletak di Kabupaten Indramayu memiliki luas 6248.52 Ha. Dari luas total areal, yang dipergunakan untuk lahan tanaman tebu adalah sekitar $8200 \mathrm{Ha}$. Selain dari areal HGU, PG Jatitujuh juga menerima pasokan tebu giling dari kebun Tebu Rakyat yang sampai tahun 2007 luasnya mencapai $1263 \mathrm{Ha}$.

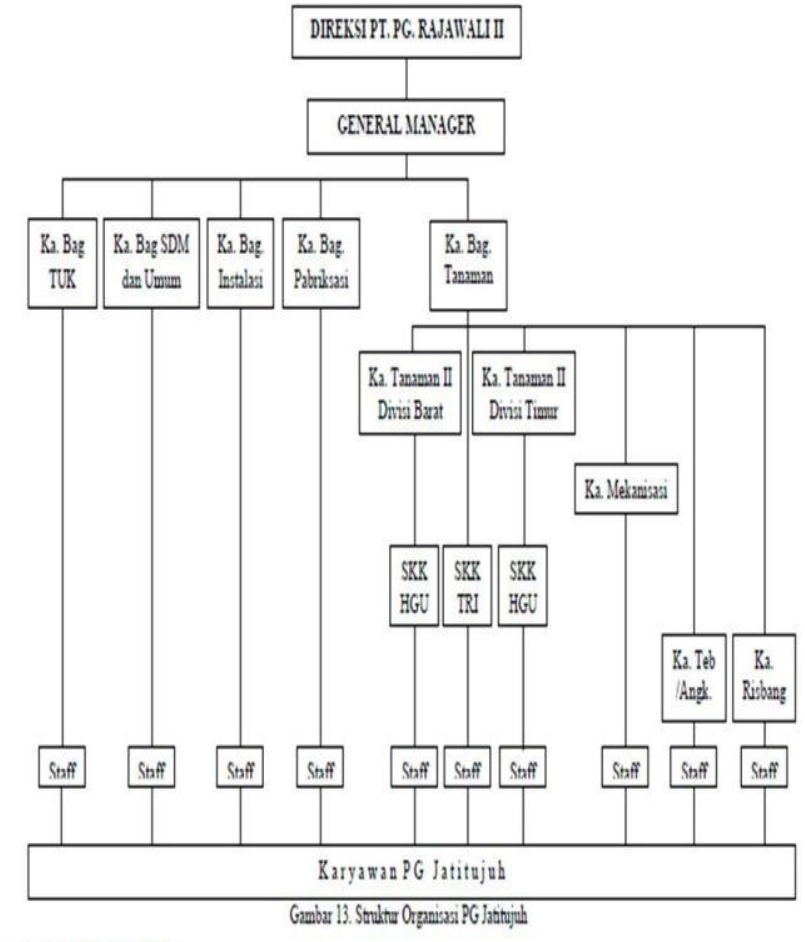

Sumber PG Jantivit (2007)

Lahan tebu HGU dibagi menjadi dua divisi wilayah yaitu Divisi Barat dan Divisi Timur. Masing-masing divisi memiliki dua rayon wilayah. Rayon yang berada di divisi sebelah barat adalah Cibenda dan Jatimunggul, sedangkan Kerticala dan Jatitujuh merupakan rayon yang berada di divisi sebelah timur. Areal yang tidak digunakan untuk tanaman tebu digunakan untuk sungai dan danau buatan, kantung air (kolam air di petak lahan), jalan, kebun hortikultura , pengeboran Pertamina , emplasemen bangunan.

\section{HASIL PENELITIAN}

\section{A. Kemitraan Sebagai Implementasi KKP-TR}

Kemitraan antara PG Jatitujuh dengan petani tebu rakyat dimulai pada tahun 2004. Sebelumnya PG Jatitujuh hanya mengandalkan tebu dari lahan HGU (Hak Guna Usaha). Kemitraan yang terjalin antara PG Jatitujuh dengan petani tebu rakyat dilaksanakan dalam rangka implementasi KKP-TR Kemitraan (Kredit Ketahanan Pangan-Tebu Rakyat). KKP-TR Kemitraan adalah Kredit Ketahanan Pangan dalam rangka pengembangan budidaya tanaman tebu rakyat yang diberikan oleh bank kepada kelompok tani yang disepakati sebagai mitra oleh pabrik gula tertentu, atau kepada Kepala Koperasi Primer yang disepakati sebagai mitra pabrik gula tertentu, untuk diteruskan kepada kelompok tani anggotanya guna membiayai budi daya tebu rakyat yang dilaksanakan dengan pola kerja sama usaha budi daya tebu. Bank sebagai pemberi KKP-TR Kemitraan adalah bank yang melaksanakan pemberian KKP-TR Kemitraan kepada koperasi dan kelompok tani.

Kemitraan antara PG Jatitujuh dengan petani tebu rakyat termasuk dalam kemitraan subkontrak. Hal ini sesuai dengan pengertian kemitraan subkontrak menurut Sumardjo, dkk (2004), bahwa kemitraan subkontrak adalah pola kemitraan antara perusahaan dengan 
kelompok mitra usaha yang memproduksi komponen yang diperlukan perusahaan mitra sebagai bagian dari produksinya.

Petani tebu rakyat sangat antusias menyambut kemitraan tersebut. Hal ini dapat dilihat dengan semakin meningkatnya luas areal lahan milik petani tebu rakyat yang semakin meningkat setiap tahunnya. Peningkatan luas areal tebu rakyat dapat dilihat pada Tabel 2.

Tabel 2. Luas Areal, Jumlah Tebu, dan

Rendemen Tebu Rakyat PG Jatitujuh Tahun 2005-2007

\begin{tabular}{|c|c|l|c|}
\hline Tahun & $\begin{array}{c}\text { Areal } \\
(\mathrm{Ha})\end{array}$ & $\begin{array}{c}\text { Jmlh Tebu } \\
(\mathrm{Ku})\end{array}$ & $\begin{array}{c}\text { Rendemen } \\
(\%)\end{array}$ \\
\hline 2005 & 442 & 286.700 & 7,06 \\
\hline 2006 & 905 & 532.862 & 7,89 \\
\hline 2007 & 1263 & 761.589 & 8,20 \\
\hline
\end{tabular}

Sumber: PG Jatitujuh (2007)

Menurut Hafsah (2003), pola kemitraan dapat dikembangkan mulai dari yang paling sederhana sampai pola ideal. Adapun KKP-TR kemitraan antara PG Jatitujuh dan petani tebu rakyat termasuk dalam pola kemitraan sederhana. Kemitraan pola sederhana adalah pengembangan usaha bisnis dengan adanya ikatan tanggung jawab dari masing-masing pihak dalam mewujudkan kemitraan usaha yang saling membutuhkan, saling menguntungkan, dan saling memperkuat. Dalam pola ini, pabrik gula memiliki kewajiban memberikan dukungan atau kemudahan dalam memperoleh modal, sarana produksi, teknologi, dan manajemen. Adapun kelompok tani wajib memberikan hasil produksinya kepada pabrik gula dengan jumlah yang telah disepakati sebelumnya.

Jika dilihat dari kondisi daerahnya, KKP-TR kemitraan termasuk dalam Kerja Sama Usaha Tani Tebu Rakyat (KSU-TR). Jenis kerja sama ini merupakan kerja sama saling menguntungkan dalam melaksanakan usaha tani tebu rakyat antara kelompok tani, KUD, dan pabrik gula. Kerja sama ini dilaksanakan guna menunjang keberhasilan program swasembada gula 2014 dengan memanfaatkan Kredit Ketahanan Pangan-Tebu Rakyat Kemitraan (KKP-TR).

Kemitraan dilakukan berdasarkan kesepakatan yang tertuang dalam perjanjian antara tiga pihak, yaitu:

\section{a. PT. PG Rajawali II Unit PG Jatitujuh}

Dalam melaksananakan kemitraan antara PT. PG Rajawali II Unit PG Jatitujuh dan petani tebu rakyat, General Manager PG Jatitujuh berkedudukan sebagai perwakilan Direksi PT. PG Rajawali II yang bertindak untuk dan atas nama PT. PG Rajawali II. Pabrik gula merupakan kepanjangan tangan dari bank dalam menyalurkan kredit untuk kelompok tani atau koperasi.

\section{b. Koperasi Manis Jaya}

Sebelum mendapatkan kredit, kelompok tani harus mendaftarkan kelompok mereka kepada koperasi. Koperasi kemudian akan memberikan ajuan kredit kepada bank. Dalam setiap PG, hanya ada satu koperasi yang berperan dalam kemitraan antara PG dengan petani tebu rakyat. Koperasi Manis Jaya merupakan koperasi kelompok tani yang bermitra dengan PG Jatitujuh.

\section{c. Kelompok Tani}

Petani tebu rakyat harus membentuk kelompok sebelum mengajukan kredit kepada bank melalui koperasi. Hal ini dilakukan agar pemberian kredit lebih efektif dan efisien. Jika kredit diberikan kepada masing-masing petani, akan membutuhkan waktu yang lama dan memakan banyak tenaga kerja. Dalam setiap kelompok tani juga terdapat ketua, sekertaris, dan bendahara. Ketua kelompok tani bertindak untuk diri sendiri maupun untuk dan atas nama kelompok tani anggotanya.

\section{Tahapan Kemitraan}

Sebelum melakukan kemitraan, ada beberapa tahapan yang harus dilalui oleh kelompok tani, yaitu:

\section{a. Pembentukan kelompok}

Petani tebu rakyat harus membentuk kelompok lebih dulu sebelum bisa mengajukan kredit. Jumlah anggota dalam satu kelompok tani mulai dari 3-10 orang. Ketua, sekretaris, dan bendahara juga harus ada dalam satu kelompok tani. Pembentukan kelompok tani bertujuan untuk memudahkan bank dan PG dalam proses pemberian kredit. Selain itu, pengajuan kredit secara berkelompok juga akan memudahkan petani dalam proses pembayaran kredit karena dilakukan secara bersama-sama.

\section{b. Pengajuan KKP-TR}

Setelah kelompok tani terbentuk, mereka mengajukan pinjaman KKP-TR kepada Koperasi Manis Jaya. Koperasi akan membuatkan Rencana Definitif Kelompok Tani (RDK) dan Rencana Definitif Kebutuhan Kelompok Tani (RDKK) untuk kelompok tani. Rencana Definitif Kelompok Tani adalah rencana kegiatan usaha dan kebutuhan modal kerja kelompok tani untuk suatu periode tertentu yang disusun melalui musyawarah dan berisikan rincian kegiatan dan kesepakatan bersama mengelola usaha budi daya tanaman dalam satu hamparan. Rencana Definitif Kebutuhan Kelompok Tani adalah rencana kebutuhan modal kerja budi daya tanaman tebu kelompok tani selama 1 (satu) periode tertentu, yang disusun berdasarkan musyawarah anggota kelompok tani dan dilengkapi dengan rencana dan pembayaran kembali KKP-TR Kemitraan.

\section{c. Penggunaan dana pinjaman}

Koperasi melakukan penarikan KKP-TR Kemitraan dari bank pelaksana berdasarkan surat kuasa dari para petani kepada koperasi. Selanjutnya koperasi menyetorkan dana kredit tersebut ke rekening giro PG Jatitujuh di bank pelaksana yang bersangkutan. Pencairan dan penggunaan dana KKP-TR Kemitraan dari rekening giro PG yang berasal dari dana KKP-TR Kemitraan yang disetorkan oleh koperasi dilaksanakan oleh pejabat yang berwenang dari PG Jatitujuh untuk keperluan 
pembiayaan budi daya tebu rakyat kelompok tani. Dalam keperluan tersebut, PG memberikan nama pejabat yang diberi wewenang memberikan rekomendasi serta contoh tanda tangannya pada waktu akad dan pencairan kredit KKP-TR Kemitraan.

\section{d. Pembayaran hasil tebu}

Kelompok tani wajib menyerahkan hasil panen tebu kepada PG Jatitujuh. Pihak PG kemudian membayar hasil penyerahan panen tebu/ gula kepada kelompok tani setelah dikurangi dengan pembayaran pokok dan bunga pinjaman kelompok tani. Selanjutnya, PG wajib menyetorkan pembayaran pokok dan bunga pinjaman ke rekening pinjaman kelompok tani di bank dari hasil penyerahan panen tebu/gula petani.

\section{Hak dan Kewajiban dalam KKP-TR Kemitraan}

Tiga pihak yang melakukan KKP-TR Kemitraan memiliki hak dan kewajibannya sendiri-sendiri dalam kemitraan, yaitu:

a. Hak masing-masing pihak:

1) PT. PG Rajawali II Unit PG Jatitujuh

i. Menetapkan koperasi dan kelompok tani yang menjadi mitra kerja dalam pelaksanaan KKP-TR Kemitraan

ii. Menerima dan mengelola tebu hasil kebun kelompok tani

iii. Memotong hasil penjualan gula kelompok tani untuk membayar kembali pinjaman pokok dan bunga KKP-TR Kemitraan atas nama kelompok tani kepada bank

2) Koperasi Manis Jaya

i. Menandatangani akad kredit

ii. Menarik kredit dan menyetorkannya ke rekening PG yang khusus dibuka untuk membiayai budi daya tebu kelompok tani di bank yang bersangkutan, berdasarkan surat kuasa dari kelompok tani kepada koperasi dan surat kuasa dari koperasi kepada pabrik gula

\section{3) Kelompok Tani}

i. Mendapatkan saprodi dan biaya lainnya dari PG Jatitujuh yang bersumber dari dana KKPTR Kemitraan

ii. Mendapatkan bimbingan teknis budi daya sampai dengan panen dan penanganan pasca panen hingga tebu yang dihasilkan sesuai standar mutu yang ditetapkan.

iii. Mendapatkan hasil sesuai sistem yang berlaku di pabrik gula yang bersangkutan, yaitu sistem pembelian tebu (SP) atau sistem bagi hasil $(\mathrm{SBH})$

b. Kewajiban masing-masing pihak:

1) PT. PG Rajawali II Unit PG Jatitujuh i. Membimbing petani dalam menyusun RDK dan RDKK tebu yang dilengkapi dengan rencana penarikan dan pengembalian kredit (RPP)

ii. Memeriksa rekapitulasi RDK dan RDKK yang dilengkapi dengan RPP serta RDK dan RDKK pendukungnya dan merekomendasikan permohonan kredit yang diajukan kelompok tani melalui koperasi kepada bank

iii. Mengelola dana KKP-TR Kemitraan yang langsung disetor oleh koperasi setelah koperasi menarik KKP-TR Kemitraan dari bank

iv. Menjamin kelancaran dan ketepatan waktu dan jumlah penyediaan bibit tebu dan saprodi serta membimbing teknis budi daya tebu

v. Mengatur dan melaksanakan tebang angkut dan pengolahan hasil tebu kelompok tani guna mencapai efisiensi yang tinggi

vi. Membayar hasil panen tebu/gula kepada kelompok tani dengan harga sesuai ketentuan/kesepakatan setelah dipotong dengan angsuran/pelunasan pinjaman pokok dan bunga kelompok tani kepada bank

vii. Menjamin pendapatan minimal yang harus diperoleh kelompok tani sesuai kesepakatan

viii. Menjamin kelancaran pengembalian KKPTR Kemitraan dan bertanggung jawab atas pelunasan seluruh kredit tersebut kepada bank sesuai jangka waktu yang diperjanjikan

2) Koperasi Manis Jaya

i. Membuat rekapitulasi RDK dan RDKK yang diajukan kelompok tani dilengkapi dengan rencana penarikan dan pengembalian kredit (RPP) serta meneruskan permohonan kredit kelompok tani kepada bank melalui PG Jatitujuh untuk mendapatkan persetujuan/ rekomendasi dari PG, dilampiri RDKK pendukung maupun dokumen yang dipersyaratkan bank

ii. Mengajukan permohonan kredit

iii. Menandatangani akad kredit

iv. Menarik kredit dari bank setelah kredit tersebut disetujui oleh bank, dan langsung menyetorkan seluruh dana KKP-TR Kemitraan yang ditarik tersebut ke rekening PG di bank pelaksana yang bersangkutan, untuk dipergunakan membiayai kegiatan budi daya tebu kelompok tani sesuai RPP

v. Membuat pernyataan pembayaran tunggakan KKPA-TRI dan KKPA-TR 
apabila Koperasi Primer yang bersangkutan mempunyai tunggakan KKPA-TRI dan KKPA-TR sebelumnya

vi. Membuat surat kuasa kepada PG Jatitujuh untuk mengelola dana KKP-TR Kemitraan guna membiayai kegiatan budi daya tebu kelompok tani

3) Kelompok Tani

i. Menyusun RDK dan RDKK yang dilengkapi dengan RPP, selanjutnya mengajukan permohonan kredit melalui koperasi kepada bank.

ii. Memberikan surat kuasa kepada Koperasi Manis Jaya untuk mengajukan permohonan kredit, menandatangani kredit, dan menarik kredit tersebut dari bank serta langsung menyetorkan kredit yang ditarik tersebut ke rekening PG di bank yang bersangkutan untuk dipergunakan membiayai kegiatan budi daya tebu kelompok tani.

iii. Melaksanakan budi daya tebu sesuai petunjuk dan bimbingan PG Jatitujuh.

iv. Menyerahkan produksi tebu kepada PG Jatitujuh untuk dibeli (dalam SPT) atau digiling (dalam SHB) sesuai kesepakatan para pihak. v. Membuat pernyataan membayar kembali tunggakan KKPA-TRI dan KKPA-TR apabila yang bersangkutan mempunyai tunggakan tersebut.

Pelaksanaan Kemitraan PG Jatitujuh dengan Petani Tebu Rakyat

Tabel 3. Nilai Rataan dan Kategori Intensitas Kemitraan antara Petani

Tebu Rakyat dan PG Jatitujuh Tahun 2010

\begin{tabular}{|c|l|c|c|}
\hline No. & \multicolumn{1}{|c|}{ Variabel } & $\begin{array}{c}\text { Rataan } \\
(\%)\end{array}$ & Kategori \\
\hline 1. & $\begin{array}{l}\text { Tingkat kerja } \\
\text { sama }\end{array}$ & 83,91 & Tinggi \\
\hline 2. & $\begin{array}{l}\text { Tingkat } \\
\text { penerapan } \\
\text { prinsip } \\
\text { kemitraan }\end{array}$ & 95,22 & Tinggi \\
\hline 3. & $\begin{array}{l}\text { Besarnya } \\
\text { kendala }\end{array}$ & 12,06 & Rendah \\
\hline 4. & $\begin{array}{l}\text { Tingkat } \\
\text { kemanfaatan } \\
\text { bermitra }\end{array}$ & 92,21 & Tinggi \\
\hline 5. & $\begin{array}{l}\text { Intensitas } \\
\text { koordinasi }\end{array}$ & 75,65 & Sedang \\
\hline
\end{tabular}

Pelaksanaan kemitraan antara PG Jatitujuh dan petani tebu rakyat termasuk dalam kategori tinggi. Hal ini dapat disimpulkan berdasarkan skor variabel dalam intensitas kemitraan, di mana tiga dari lima variabel termasuk dalam kategori tinggi. Rendahnya kendala tidak berarti negatif, sebaliknya rendahnya kendala juga menandakan kemitraan berjalan sesuai dengan ketentuan yang ada.

\section{B. Kemitraan Membantu dalam Memberdayakan Masyarakat}

Awalnya para petani tebu melakukan kemitraan dengan PG Khadipaten, namun PG tersebut harus ditutup karena mengalami masalah dalam keuangan. Akhirnya para petani tebu banyak yang beralih menjadi petani padi atau beralih ke sektor pekerjaan yang lain. Peralihan ini disebabkan karena petani tebu tidak memiliki cukup modal untuk melakukan budi daya tebu. Dibutuhkan modal yang besar untuk menanam tebu, apalagi panen yang hanya dilakukan satu tahun sekali sehingga petani juga harus memiliki modal untuk membiayai hidup sebelum panen tiba

Pada tahun 2004, PG Jatitujuh membuka peluang bagi petani tebu untuk kembali melakukan budi daya tebu. Pabrik gula menawarkan kredit budi daya tebu yang syaratnya cukup mudah dan bunga kredit yang tidak terlalu besar. Awalnya hanya sedikit saja yang tertarik untuk melakukan kemitraan dengan PG Jatitujuh. Namun melihat keberhasilan dan keuntungan yang didapat petani tebu yang melakukan kemitraan, petani tebu yang lain mulai tertarik sehingga makin lama makin banyak petani tebu yang bermitra dengan PG Jatitujuh.

Kemitraan antara PG Jatitujuh sangat membantu masyarakat di sekitar pabrik, baik dalam hal memperbaiki tingkat perekonomian masyarakat maupun dalam hal mengurangi jumlah pengangguran. Bahkan saat panen, petani tebu sampai mengambil tenaga kerja dari daerah lain karena banyaknya tenaga kerja yang dibutuhkan. Tingkat ekonomi petani juga meningkat karena petani tebu turut serta menentukan harga jual gula sehingga petani tebu tidak dirugikan. Lahan-lahan tidur pun menjadi berkurang jumlahnya karena

diubah menjadi areal budi daya tebu. Lahan tersebut tidak digunakan karena tidak cocok untuk budi daya padi, tetapi cocok untuk budi daya tebu. Dengan demikian kemitraan antara PG Jatitujuh dan petani tebu sesuai dengan kondisi lingkungan di sekitar pabrik.

\section{Analisis Variabel Keberdayaan Masyarakat Dalam Kemitraan}

Keberdayaan masyarakat adalah sejauh mana masyarakat dapat memanfaatkan potensi dan sumber daya yang mereka miliki untuk bisa mandiri. Keberdayaan masyarakat dalam penelitian ini dilihat dari tingkat partisipasi petani tebu dalam kemitraan, kesesuaian antara program kemitraan dengan kebutuhan masyarakat, kesesuaian antara program kemitraan dengan potensi masyarakat, dan besarnya motivasi dalam mengikuti kemitraan. Setelah dihitung dengan rumus nilai rataan, seluruh variabel masuk dalam kategori tinggi. 
Tabel 4. Nilai Rataan dan Kategori Tingkat Keberdayaan Petani Tebu Rakyat di Majalengka Tahun 2010

\begin{tabular}{|c|l|c|c|}
\hline No. & \multicolumn{1}{|c|}{ Variabel } & $\begin{array}{c}\text { Rataan } \\
(\%)\end{array}$ & Kategori \\
\hline 1. & $\begin{array}{l}\text { Tingkat } \\
\text { partisipasi }\end{array}$ & 87,11 & Tinggi \\
\hline 2. & $\begin{array}{l}\text { Kesesuaian } \\
\text { dengan } \\
\text { kebutuhan } \\
\text { masyarakat }\end{array}$ & 97,39 & Tinggi \\
\hline 3. & $\begin{array}{l}\text { Kesesuaian } \\
\text { dengan potensi } \\
\text { masyarakat }\end{array}$ & 94,78 & Tinggi \\
\hline 4. & $\begin{array}{l}\text { Besarnya } \\
\text { motivasi }\end{array}$ & 84,42 & Tinggi \\
\hline
\end{tabular}

\section{Hubungan antara Variabel Intensitas Kemitraan dengan Variabel Keberdayaan Masyarakat}

Jika dilihat secara keseluruhan, tidak ada hubungan nyata dan positif antara intensitas kemitraan dan keberdayaan masyarakat. Namun, jika dilihat dari satu persatu variabel, ada beberapa variabel yang memiliki hubungan nyata dan positif. Tidak ada satu variabel pun yang berhubungan nyata dan negatif.

Berdasarkan data pada Tabel 5. dapat dilihat bahwa tingkat kerja sama memiliki hubungan nyata dan positif dengan keberdayaan masyarakat. Semakin tinggi kerja sama antara PG Jatitujuh dan petani tebu rakyat, maka akan semakin tinggi pula keberdayaan masyarakat, khususnya petani tebu. Variabel keberdayaan masyarakat yang memiliki hubungan dengan tingkat kerja sama adalah tingkat partisipasi. Tingginya tingkat partisipasi petani tebu dalam kemitraan akan membuat kerja sama semakin baik. Kerja sama yang tercipta antara PG dan petani tebu yang berjalan dengan baik, membuat petani tebu menjadi terbuka dalam mengeluarkan pendapat sehingga tercipta partisipasi yang tinggi dari petani.

Intensitas koordinasi juga memiliki hubungan positif dan nyata dengan keberdayaan masyarakat. Variabel keberdayaan masyarakat yang memiliki hubungan dengan intensitas koordinasi adalah tingkat partisipasi. Pada Tabel 5. dapat dilihat bahwa ada hubungan nyata dan positif antara intensitas koordinasi dengan tingkat partisipasi. Tingginya upaya PG untuk menciptakan keterpaduan yang baik antara kemitraan dan petani tebu membuat PG menghargai partipasi dari petani tebu.

Intensitas kemitraan memiliki hubungan nyata dan positif dengan tingkat partisipasi. Pabrik gula menghargai partisipasi dari para petani tebu agar kemitraan berjalan baik dan lancar. Variabel intensitas kemitraan yang berhubungan dengan tingkat partisipasi adalah tingkat kerja sama dan intensitas koordinasi. Tingkat kerja sama yang baik dan tingginya upaya PG untuk menciptakan keterpaduan akan membuat tingginya tingkat partisipasi petani tebu.
Tabel 5. Koefisien Korelasi Rank Speaman antara Varipbel Intensitas Kemitraan dan Variabel Keberdayaan Masyarakat

\begin{tabular}{|c|c|c|c|c|c|}
\hline \multirow{2}{*}{$\begin{array}{c}\text { Intensitas } \\
\text { kemitraan } \\
\left(X_{l}\right)\end{array}$} & \multicolumn{5}{|c|}{ Tingkat Keberdayaan masyarakat $\left(\mathrm{Y}_{2}\right)$} \\
\hline & $\begin{array}{c}\text { Tingkat } \\
\text { partisipasi } \\
\left(\mathrm{Y}_{2.1}\right)\end{array}$ & $\begin{array}{c}\text { Kesesuaian } \\
\text { dengan kebutuban } \\
\text { masyarakat }\left(Y_{22}\right)\end{array}$ & $\begin{array}{c}\text { Kesesuaian } \\
\text { dengan potensi } \\
\text { masyarakat }\left(\mathrm{Y}_{23}\right)\end{array}$ & $\begin{array}{c}\text { Besarnya } \\
\text { motivasi } \\
\left(\mathrm{Y}_{24}\right)\end{array}$ & Total \\
\hline $\begin{array}{l}\text { Tingkat kejja } \\
\operatorname{sama}\left(X_{1: 1}\right)\end{array}$ &, $403 * *$ &, 114 &, 234 & -032 &, $334^{*}$ \\
\hline $\begin{array}{l}\text { Tingkat } \\
\text { penerapan } \\
\text { prinsip } \\
\text { kemitraan }\left(X_{12}\right)\end{array}$ &, 117 &, 022 & 047 &, 259 &, 250 \\
\hline $\begin{array}{l}\text { Besamya } \\
\text { kendala }\left(\mathrm{X}_{13}\right)\end{array}$ & 128 & -260 & -213 & -042 & -056 \\
\hline $\begin{array}{l}\text { Tingkat } \\
\text { kemanfaatan } \\
\text { bermitra }\left(X_{1,4}\right)\end{array}$ & 168 &, 148 & -026 & -045 &, 101 \\
\hline $\begin{array}{l}\text { Intensitas } \\
\text { kooodinasi }\left(X_{L S}\right)\end{array}$ &, $421^{* *}$ &, 165 & 086 &, 114 &, $322^{*}$ \\
\hline Total &, $402^{* *}$ & -072 & - 180 &, 199 &, 246 \\
\hline
\end{tabular}

\section{Efektivitas Kemitraan Bagi Petani Tebu Rakyat}

Efektivitas kemitraan dalam penelitian ini dilihat dari sudut pandang petani, bukan menurut PG. Efektivitas petani adalah sejauh mana kemitraan membawa dampak positif bagi petani dalam melakukan kegiatan budidaya tebu. Dari enam variabel kemitraan, lima variabel bernilai tinggi. Dengan demikian, dapat dinyatakan bahwa efektivitas kemitraan termasuk baik dan pelaksanaan kemitraan berdampak positif bagi petani tebu.

\section{Tabel 6. Nilai Rataan dan Kategori Efektivitas Kemitraan antara Petani Tebu Rakyat dengan PG Jatitujuh Tahun 2010}

\begin{tabular}{|c|l|r|c|}
\hline No & \multicolumn{1}{|c|}{ Variabel } & Rataan & Kategori \\
\hline 1. & $\begin{array}{l}\text { Aksesibilitas } \\
\text { permodalan }\end{array}$ & 77,82 & Tinggi \\
\hline 2. & $\begin{array}{l}\text { Kelancaran } \\
\text { pemasaran }\end{array}$ & 96,74 & Tinggi \\
\hline 3. & $\begin{array}{l}\text { Tingkat } \\
\text { modernisasi alat }\end{array}$ & 78,04 & Tinggi \\
\hline 4. & $\begin{array}{l}\text { Tingkat } \\
\text { kemampuan }\end{array}$ & 86,30 & Tinggi \\
\hline 5. & $\begin{array}{l}\text { Kerapihan } \\
\text { keuangan }\end{array}$ & 31,30 & Rendah \\
\hline 6. & $\begin{array}{l}\text { Tingkat } \\
\text { Keuntungan }\end{array}$ & 86,74 & Tinggi \\
\hline
\end{tabular}

\section{Hubungan antara Variabel Intensitas Kemitraan dengan Variabel Efektivitas Kemitraan}

Dalam Tabel 7. dapat dilihat bahwa tingkat kerja sama dan efektivitas kemitraan memiliki hubungan positif dan nyata. Variabel efektivitas kemitraan yang berhubungan 
dengan tingkat kerja sama adalah tingkat kemampuan dan tingkat keuntungan. Semakin tinggi tingkat kerja sama antara PG dan petani tebu, maka akan semakin tinggi pula kemampuan yang dimiliki oleh petani. Sebaliknya, semakin rendah tingkat kerja sama antara PG dan petani tebu, semakin rendah pula tingkat kemampuan yang dimiliki petani tebu. Hal ini terjadi karena dengan terbukanya kesempatan petani untuk bekerja sama dengan PG dalam kemitraan, maka kemampuan petani akan semakin terasah dan semakin meningkat. Hubungan nyata dan positif juga ada antara tingkat kerja sama dan tingkat keuntungan. Semakin tinggi kerja sama antara PG dan petani tebu, maka akan semakin tinggi pula keuntungan yang didapat petani.

Tingkat penerapan prinsip kemitraan dengan kerapihan keuangan juga memiliki hubungan nyata dan positif. Jika pelaksanaan kemitraan menerapkan prinsip-prinsip kemitraan dengan baik dan benar, pencatatan keuangan petani juga akan rapi dan baik. Selain itu, tingkat penerapan prinsip kemitraan juga memiliki hubungan nyata dan positif dengan tingkat keuntungan. Salah satu prinsip dalam kemitraan adalah saling menguntungkan. Dengan demikian, jika prinsip kemitraan diterapkan dengan baik, maka tingkat keuntungan juga akan meningkat.

Tabel 7. Koefisien Korelasi Rank Spearman antara Variabel Intensitas Kemitraan dan Variabel Efektivitas Kemitraan

\begin{tabular}{|l|c|c|c|c|c|c|c|}
\hline \multirow{2}{*}{$\begin{array}{c}\text { Intensitas kemitraan } \\
\left(\mathrm{X}_{1}\right)\end{array}$} & \multicolumn{7}{|c|}{ Efektivitas kemitraan $\left(\mathrm{Y}_{1}\right)$} \\
\cline { 2 - 8 } & $\mathrm{Y}_{1.1}$ & $\mathrm{Y}_{1.2}$ & $\mathrm{Y}_{1.3}$ & $\mathrm{Y}_{1.4}$ & $\mathrm{Y}_{1.5}$ & $\mathrm{Y}_{1.6}$ & Total \\
\hline Tingkat kerja sama $\left(\mathrm{X}_{1.1}\right)$ &, 265 &, 120 &, 237 &, $408^{* *}$ &, 245 &, $323^{*}$ &, $416^{* *}$ \\
\hline $\begin{array}{l}\text { Tingkat penerapan prinsip } \\
\text { kemitraan }\left(\mathrm{X}_{1.2}\right)\end{array}$ &,- 099 &,- 008 &,- 086 &, 205 &, $335^{*}$ &, $440^{* *}$ &, 257 \\
\hline Besarnya kendala $\left(\mathrm{X}_{1.3}\right)$ &,$- 316^{*}$ &,- 242 &,- 042 &,$- 331^{*}$ &,- 152 & -258 &,$- 325^{*}$ \\
\hline $\begin{array}{l}\text { Tingkat kemanfaatan } \\
\text { bermitra }\left(\mathrm{X}_{1.4}\right)\end{array}$ &, 004 &, 043 &, $313^{*}$ &, 156 &, 042 &, 165 &, 215 \\
\hline $\begin{array}{l}\text { Intensitas koordinasi } \\
\left(\mathrm{X}_{1.5}\right)\end{array}$ &, $323^{*}$ &, 020 &,- 018 &, 194 &, 216 &, $376^{* *}$ &, $331^{*}$ \\
\hline Total &, 079 &,- 241 &, 059 &, 138 &, 168 &, 265 &, 226 \\
\hline
\end{tabular}

Keterangan : ${ }^{* 8}$ berhubungan pada taraf nyata 0,01

* berhubungan pada taraf nyata 0,05

$$
\begin{array}{ll}
\mathrm{Y}_{11}=\text { Aksesibilitas permodalan } & \mathrm{Y}_{14}=\text { Tingkat kemampuan } \\
\mathrm{Y}_{12}=\text { Kelancaran pemasaran } & \mathrm{Y}_{15}=\text { Kerapihan keuangan } \\
\mathrm{Y}_{13}=\text { Tingkat modemisasi alat } & \mathrm{Y}_{1 \mathrm{n}}=\text { Tingkat keuntungan }
\end{array}
$$

Besarnya kendala juga memiliki hubungan nyata dan negatif dengan efektivitas kemitraan. Namun, hubungan negatif ini tidak berarti buruk justru berarti baik. Semakin sedikit kendala yang dihadapai petani dalam kemitraan, semakin tinggi efektivitas kemitraan. Variabel efektivitas kemitraan yang berhubungan dengan besarnya kendala adalah aksesibilitas modal dan tingkat kemampuan. Besarnya kendala dengan aksesibilitas modal memiliki hubungan nyata dan negatif. Semakin besar kendala yang dihadapi dalam pelaksanaan kemitraan, tidak akan membuat aksesibilitas modal semakin tinggi. Namun, semakin rendah kendala yang dihadapi, maka akan semakin tinggi aksesibilitas modal dalam kemitraan. Hal ini terjadi karena adanya kendala dalam kemitraan akan membuat aksesibilitas modal tersendat. Jadi, jika tidak ada kendala dalam kemitraan, akses untuk mendapatkan modal akan semakin mudah. Besarnya kendala juga memiliki hubungan nyata dan negatif dengan tingkat kemampuan. Jika petani mengalami banyak kendala dalam budidaya tebu, kemampuan petani dalam budidaya akan menurun.

Tingkat kemanfaatan bermitra memiliki hubungan nyata dan positif dengan tingkat modernisasi alat. Salah satu manfaat yang didapat petani dari bermitra adalah kemajuan dalam teknologi pertanian yang digunakan. Semakin tinggi tingkat kemanfaatan bermitra yang didapat petani, maka akan semakin tinggi pula tingkat modernisasi alat yang dimiliki petani.

Intensitas koordinasi juga memiliki hubungan nyata dan positif dengan efektivitas kemitraan. Semakin tinggi intensitas kemitraan, maka akan semakin tinggi pula efektivitas kemitraan. Variabel efektivitas kemitraan yang memiliki hubungan dengan intensitas koordinasi adalah aksesibilitas modal dan tingkat keuntungan. Ada hubungan nyata dan positif antara intensitas koordinasi dan aksesibilitas permodalan. Koordinasi yang baik akan memudahkan petani dalam mendapatkan modal, baik modal keuangan maupun modal peralatan. Selain itu, intensitas koordinasi juga memiliki hubungan nyata dan positif dengan tingkat keuntungan. Koordinasi yang baik akan menjadikan pelaksanaan kemitraan berjalan dengan baik yang pada akhirnya dapat meningkatkan keuntungan.

\section{Hubungan antara Variabel Keberdayaan Masyarakat dengan Variabel Efektivitas Kemitraan}

Berdasarkan hasil penelitian, didapat bahwa ada hubungan nyata dan positif antara efektivitas kemitraan dan keberdayaan masyarakat. Beberapa variabel dalam efektivitas kemitraan dan keberdayaan masyarakat juga memiliki hubungan nyata dan positif. Secara rinci dapat dilihat pada Tabel 8 .

Ada hubungan nyata dan positif antara tingkat partisipasi dan efektivitas kemitraan. Semakin tinggi partisipasi petani tebu dalam kemitraan, maka semakin tinggi pula efektivitas kemitraan yang didapat petani. Variabel efektivitas kemitraan yang berhubungan dengan tingkat partisipasi adalah tingkat modernisasi alat, kerapihan keuangan, dan tingkat keuntungan. Hubungan nyata dan positif terdapat antara tingkat partisipasi dan tingkat modernisasi alat. Kebebasan petani dalam mengeluarkan pendapat akan berdampak pada majunya teknologi yang digunakan petani dalam melakukan budidaya tebu. Jika peralatan yang digunakan tidak baik atau memperlambat proses budidaya, petani dapat mengajukan permintaan perbaikan kepada PG. Tingkat partisipasi juga memiliki hubungan nyata dan positif dengan kerapihan keuangan. Keterbukaan dan kebebasan petani dalam mengeluarkan pendapat dalam kemitraan akan memudahkan petani dalam mencatat keuangan dalam kegiatan budidaya. Selain itu, ada juga hubungan nyata dan positif antara tingkat partisipasi dan tingkat keuntungan. Hal ini

168 Fadilah, Ratna. et. al. Analisis Kemitraan Antara Pabrik Gula Jatitujuh dengan Petani Tebu Rakyat di Majalengka, Jawa Barat 
terjadi karena PG menghargai pendapat petani dan mengutamakan kepentingan petani sehingga tingkat keuntungan yang didapat petani pun akan meningkat.

Ada hubungan nyata dan positif antara kesesuaian program kemitraan dengan kebutuhan masyarakat terhadap aksesibilitas permodalan. Pihak PG yang ingin memenuhi kebutuhan petani tebu dalam melakukan budidaya akan memenuhi kebutuhan petani akan modal.

Ada hubungan nyata dan positif antara kesesuaian program dengan potensi masyarakat terhadap aksesibilitas modal. Dalam rangka menggali potensi masyarakat dalam bidang pertanian, PG akan memberikan aksesibilitas modal yang mudah agar potensi masyarakat dapat tergali dengan baik.

Tabel 8. Koefisien Korelasi Rank Spearman antara Variabel Keberdayaan Masyarakat dan Variabel Efektivitas Kemitraan

\begin{tabular}{|l|c|c|c|c|c|c|c|}
\hline \multirow{2}{*}{$\begin{array}{c}\text { Keberdayaan masyarakat } \\
\left(\mathrm{Y}_{2}\right)\end{array}$} & \multicolumn{7}{|c|}{ Efektivitas kemitraan $\left(\mathrm{Y}_{1}\right)$} \\
\cline { 2 - 8 } & $\mathrm{Y}_{1.1}$ & $\mathrm{Y}_{1.2}$ & $\mathrm{Y}_{1.3}$ & $\mathrm{Y}_{1.4}$ & $\mathrm{Y}_{1.5}$ & $\mathrm{Y}_{1.6}$ & Total \\
\hline Tingkat partisipasi $\left(\mathrm{Y}_{2.1}\right)$ &, 075 & -121 &, $428^{* *}$ &, 221 &, $333^{*}$ &, $338^{*}$ &, $420^{* *}$ \\
\hline $\begin{array}{l}\text { Kesesuaian dengan } \\
\text { kebutuhan }\left(\mathrm{Y}_{22.2}\right.\end{array}$ &, $347^{*}$ &, 258 &, 016 &, 080 &, 189 &,- 004 &, 145 \\
\hline $\begin{array}{l}\text { Kesestaian dengan } \\
\text { potensi masyarakat }\left(\mathrm{Y}_{23}\right)\end{array}$ &, $308^{*}$ &, 286 &, 083 &, 189 &, 164 &, 041 &, 177 \\
\hline Besamiya motivasi $\left(\mathrm{Y}_{24}\right)$ &, 075 &, 061 &,- 087 &, 133 &, 109 &, 184 &, 165 \\
\hline Total &, 147 &, 062 &, $327 *$ &, $319^{*}$ &, $446^{* *}$ &, $367 *$ &, $526^{* *}$ \\
\hline
\end{tabular}

Keterangan: * berhubungan pada taraf nyata 0,05

${ }^{*}$ berhubungan pada taraf nyata 0,01

$\mathrm{Y}_{11}=$ Aksesibilitas permodalan $\quad \mathrm{Y}_{14}=$ Tingkat kemampuan

$\mathrm{Y}_{12}=$ Kelancaran pemasaran $\quad \mathrm{Y}_{15}=$ Kerapihan keuangan

$\mathrm{Y}_{13}=$ Tingkat modemisasi alat $\quad \mathrm{Y}_{16}=$ Tingkat keuntungan

Ada hubungan nyata dan positif Hubungan nyata dan positif terdapat antara

\section{KESIMPULAN DAN SARAN}

\section{Kesimpulan}

Pelaksanaan kemitraan antara PG Jatitujuh dan petani tebu rakyat sudah berjalan sesuai dengan maksud dan tujuan kemitraan, yaitu win-win solution atau saling menguntungkan. Tiga dari lima aspek kemitraan bernilai tinggi, yaitu tingkat kerja sama, tingkat penerapan prinsip kemitraan, dan tingkat kemanfaatan bermitra sehingga dapat diketahui bahwa kedua belah pihak mendapatkan keuntungan dari bermitra. Hanya satu aspek yang bernilai rendah, yaitu kendala. Hal ini tidak berarti negatif karena rendahnya kendala yang dihadapi petani tebu dalam kemitraan menandakan kemitraan berjalan dengan serasi.

Keberdayaan masyarakat dalam pelaksanaan kemitraan termasuk tinggi. Seluruh variabel keberdayaan masyarakat bernilai tinggi. Hal ini berarti bahwa kemitraan membantu dalam memberdayakan masyarakat, khususnya petani tebu.

Efektivitas kemitraan bagi petani tebu termasuk tinggi. Lima dari enam aspek efektivitas kemitraan bernilai tinggi, yaitu aksesibilitas permodalan, kelancaran pemasaran, tingkat modernisasi alat, tingkat kemampuan, dan tingkat keuntungan. Hanya satu variabel yang bernilai rendah, yaitu kerapihan keuangan. Dengan demikian, dapat disimpulkan bahwa petani tebu merasakan hasil yang positif dengan adanya kemitraan.

\section{Saran}

Para petani tebu hendaknya memiliki catatan keuangan yang teratur dan rapi agar keuangan usaha tidak tercampur dengan keuangan keluarga. Petani tebu supaya mencatat semua hal yang berkaitan dengan keuangan selama melalukan budidaya tebu hingga panen. Catatan tersebut jangan dicampur dengan catatan keuangan keluarga atau rumah tangga petani tebu sehingga petani tebu mengetahui keseluruhan biaya yang dibutuhkan selama budidaya tebu hingga panen. Selain itu, pencatatan keuangan juga berguna untuk mengetahui perkembangan usaha para petani. Petani tebu hendaknya tidak hanya mengandalkan DPC APTRI dalam menyimpan catatan keuangan mereka. Lebih baik petani juga memiliki catatan keuangan sendiri dan menggunakan catatan di DPC APTRI sebagai cadangan jika terjadi sesuatu terhadap catatan keuangan pribadi. Pihak PG juga sebaiknya memberikan arahan dan bimbingan kepada petani dalam urusan pencatatan keuangan usaha.

Pihak PG supaya lebih sering dan intens dalam melakukan supervisi jalannya kemitraan di lapang. Dengan demikian, petani tebu bisa lebih cepat dan mudah dalam melaporkan jika ada kendala di lapangan. Jumlah SKK (Sinder Kepala Kebun) hendaknya ditambah, apalagi mengingat jumlah luas kebun yang selalu meningkat setiap tahunnya.

\section{DAFTAR PUSTAKA}

Anonim. 2008. Tahun 2014, Indonesia Swasembada Gula. Pasuruan (http://www.indonesia.go.id/id/index.php/files/pi dato/index.php?option=com_content $\&$ task=view $\& i d=8220 \&$ Itemid=827) $($ diakses tanggal $29 \mathrm{Mei}$ 2010, pukul 13.20 WIB)

Hafsah, Mohammad Jafar. 2000. Kemitraan Usaha Konsepsi dan Strategi. PT. Pustaka Sinar Harapan. Jakarta.

Hafsah, Mohamad Jafar. 2003. Bisnis Gula di Indonesia. PT. Pustaka Sinar Harapan. Jakarta.

Ikatan Ahli Gula Indonesia. 1975. Pertemuan II anggota IKAGI. Pengurus Pusat Ikatan Ahli Gula Indonesia. Yogyakarta.

Nasdian, Fredian Tonny. 2006. Pengembangan Masyarakat (Community Development). Bagian Sosiologi Pedesaan dan Pengembangan Masyarakat, Departemen Komunikasi dan Pengembangan Masyarakat, Institut Pertanian Bogor. Bogor.

Marno. 2006. Pemberdayaan Pengrajin Kecil Melalui Kemitraan Dengan Pemilik Modal Pada Industri 
Genteng Di Desa Malanggaten Kecamatan Kebakkramat, Kabupaten Karanganyar, Provinsi Jawa Tengah. Tesis. Pascasarjana: Institut Pertanian Bogor.

Partomo, Tiktik Sartika. 2004. Ekonomi Skala Kecil/ Menengah dan Koperasi. Ghalia Indonesia. Bogor.

PG Jatitujuh, Risbang. 2007. Company Profile PT. PG Rajawali II Unit PG Jatitujuh. Cirebon

Prijono, Onny S. Dan A.M.W. Pranarka. 1996. Pemberdayaan: Konsep, Kebijakan dan Implementasi. Centre for Strategic and International Studies (CSIS). Jakarta.

Puspitawati, Eka. 2006. Analisis Kemitraan antara PT PERTANI (PERSERO) dengan Petani Penangkar Benih Padi di Kabupaten Karawang. Tesis. Program Pascasarjana: Institut Pertanian Bogor

Singarimbun, Masri dan Sofian Effendi. 1995. Metode Penelitian Survei. PT Pustaka LP3ES Indonesia. Jakarta.

Sumardjo, dkk. 2004. Teori dan Praktik Kemitraan Agribisnis. Penebar Swadaya. Jakarta.

Sumodiningrat, Gunawan. 2009. Mewujudkan Kesejahteraan Bangsa Menanggulangi Kemiskinan dengan Prinsip Pemberdayaan Masyarakat. PT Elex Media Komputindo Jakarta.

\section{LAIPIRAN}

Nilai Skor Rataan

Perhitungan Transformasi Intensitas Kemitraan

$$
\begin{aligned}
\text { 1) Tingkat kerja sama } & =\frac{616-(5 \times 46)}{(15 \times 46)-(5 \times 46)} \times 100 \%=83,91 \% \\
\text { 2) Prinsip kemitraan } & =\frac{668-(5 \times 46)}{(15 \times 46)-(5 \times 46)} \times 100 \%=95,22 \% \\
\text { 3) Besamya kendala } & =\frac{571-(10 \times 46)}{(30 \times 46)-(10 \times 46)} \times 100 \%=12,06 \% \\
\text { 4) Manfaat bermitra } & =\frac{785-(6 \times 46)}{(18 \times 46)-(6 \times 46)} \times 100 \%=92,21 \% \\
\text { 5) Intensitas koordinasi } & =\frac{578-(5 \times 46)}{(15 \times 46)-(5 \times 46)} \times 100 \%=75,65 \%
\end{aligned}
$$

Perhitungan Transformasi Keberdayaan Masyarakat

$$
\begin{aligned}
\text { 1) Tinglat partisipasi } & =\frac{883-(7 \times 46)}{(21 \times 46)-(7 \times 46)} \times 100 \%=87,11 \% \\
\text { 2) Sesuai kebutuhan } & =\frac{678-(5 \times 46)}{(15 \times 46)-(5 \times 46)} \times 100 \%=97,39 \% \\
\text { 3) Sesua potensi } & =\frac{666-(5 \times 46)}{(15 \times 46)-(5 \times 46)} \times 100 \%=94,78 \% \\
\text { 4) Besamya motivasi } & =\frac{742-(6 \times 46)}{(18 \times 46)-(6 \times 46)} \times 100 \%=84,42 \%
\end{aligned}
$$

\begin{tabular}{|c|c|c|c|c|c|c|c|}
\hline & $Y_{1}$ & $Y_{11}$ & $Y_{12}$ & $Y_{13}$ & $Y_{16}$ & $Y_{15}$ & $Y_{16}$ \\
\hline$X_{1}$ Conelation Coefficient & 226 & .079 & $.24 !$ & .059 & .138 & 168 & 265 \\
\hline Siz. 2 & .131 & .603 & .106 & .699 & .361 & 266 & .075 \\
\hline $\mathrm{N}$ & 46 & 46 & 46 & 46 & 46 & 46 & \\
\hline $\mathrm{X}_{11}$ Correlation Coefficient & $416^{\mathrm{nz}}$ & 265 &, 120 &, 237 & $408^{21}$ & .245 &, $323^{x}$ \\
\hline Sig. (2. & .004 & .075 & 426 & .113 & .005 & $.10 !$ & .208 \\
\hline $\mathrm{N}$ & 46 & 46 & 46 & 46 & 46 & 46 & 46 \\
\hline $\bar{X}_{12}$ Correlation Coefficient & 257 & .099 & .008 & .086 & 205 & $.335^{*}$ &, 44048 \\
\hline Sig. (2-Tuled) & 085 & ,511 &, 958 &, 568 &, 171 & .023 &, 002 \\
\hline $\mathrm{N}$ & 46 & 46 & 46 & 46 & 46 & 46 & 46 \\
\hline $\bar{X}$ X, Come & .3254 & $.316^{\prime}$ & .242 & $.04 ?$ & $.33 !^{\prime}$ & .152 & .258 \\
\hline Sit 2 &, 027 &, 032 & 105 &, 780 &, 025 &, 313 & 0183 \\
\hline $\mathrm{N}$ & 46 & 46 & 46 & 46 & 46 & 46 & 46 \\
\hline $\mathrm{X}_{1}$ Comelatos Coufficinat & 215 &, 004 &, 043 & 3134 &, 156 & $04 ?$ & .163 \\
\hline Sig: (2.Tulest) & , 15! & 979 &, 775 &, 034 & 302 &, 783 & .274 \\
\hline $\mathrm{N}$ & 46 & 46 & 46 & 46 & 46 & 46 & 46 \\
\hline $\mathrm{X}_{1}$ Comelatoo Coeticiest & $33 !^{\prime}$ & 3234 &, 020 &, 018 &, 194 & 216 &, 37611 \\
\hline Sif (2.T21/N) & 025 & .028 & .897 & 908 & 197 & 150 & 010 \\
\hline $\mathrm{N}$ & 46 & 46 & 46 & 46 & 46 & 46 & 46 \\
\hline
\end{tabular}

Perhitungan Transformasi Efeltivitas Kemitraan

$$
\begin{aligned}
& \text { 1) Alsses modal } \\
& =\frac{588-(5 \times 46)}{(15 \times 46)-(5 \times 46)} \times 100 \%=77,82 \% \\
& \text { 2) Pemasaran } \\
& =675-(5 \times 46) \quad \times 100 \%=96,74 \%
\end{aligned}
$$

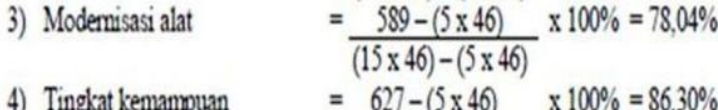

$$
\begin{aligned}
& (15 \times 46)-(5 \times 46) \\
& \text { 4) Tingkat kemampuan }=\frac{627-(5 \times 46)}{(15 \times 46)-(5 \times 46)} \times 100 \%=86,30 \% \\
& \text { 5) Ketangan }=374-(5 \times 46) \times 100 \%=31,30 \% \\
& \text { 6) Keuntungan } \quad=\frac{629-(5 \times 46)}{2} \times 100 \%=86,74 \% \\
& (15 \times 46)-(5 \times 46)
\end{aligned}
$$

Hasil Olahan Data Korelasi dengan Rank Spearman

Hasil olahan data korelasi hubungan antara intensitas kemitraan dan efeltivitas kemitraan 
Hasil olahan data Lorelasi Lubungan antara intensitas kemitraan dan keberdayaan masyaralat

\begin{tabular}{|c|c|c|c|c|c|}
\hline & $Y_{2}$ & $Y_{2}$ & $Y_{12}$ & $Y_{23}$ & $Y_{24}$ \\
\hline$X_{1}$ Conelation Coefficient &, 246 &, $402^{28}$ & .072 &, 180 &, 199 \\
\hline Sig. (2-Taled) & , 999 &, 006 &, 636 &, 233 & , 186 \\
\hline $\mathrm{N}$ & 46 & 46 & 46 & 46 & 46 \\
\hline $\bar{X}_{\mid 1}$ Comelation Coefficient &, $334^{8}$ &, $403^{38}$ &, 114 & .234 & .032 \\
\hline Siz. (2.Tuled) &, 023 &, 005 &, 450 & 1117 &, 833 \\
\hline $\mathrm{N}$ & 46 & 46 & 46 & 46 & 46 \\
\hline $\bar{X}_{12}$ Correlaton Coefficient &, 250 &, 117 & 022 & 047 & .259 \\
\hline Sig. (2.Taled) & , 994 &, 437 &, 882 &, 756 & ,08? \\
\hline $\mathrm{N}$ & 46 & 46 & 46 & 46 & 46 \\
\hline $\mathrm{X}_{13}$ Correlation Coefficient & 056 &, 128 & .260 & .213 & $;, 042$ \\
\hline Sig. (2-Tailed) &, 714 &, 395 & 081 &, 156 &, 783 \\
\hline $\mathrm{N}$ & 46 & 46 & 46 & 46 & 46 \\
\hline $\mathrm{X}_{16}$ Correlation Coefficient &, $10 !$ &, 168 &, 148 & .026 & .045 \\
\hline Sig. (2.Tailed) &, 506 & 265 &, 328 & 862 &, 764 \\
\hline $\mathrm{N}$ & 46 & 46 & 46 & 46 & 46 \\
\hline $\mathrm{X}_{15}$ Correlation Coefficient & $322^{*}$ &, $421^{* 8}$ & .072 & .180 &, 114 \\
\hline Sig̨ (2-Tuled) &, 029 &, 004 &, 636 &, 233 &, 453 \\
\hline $\mathrm{N}$ & 46 & 46 & 46 & 46 & 46 \\
\hline
\end{tabular}

Hasil olahan data korelasi hubungan antara intensitas kemitraan dan keberdayaan masyarakat

\begin{tabular}{|c|c|c|c|c|c|}
\hline & $Y_{2}$ & $Y_{21}$ & $Y_{12}$ & $Y_{23}$ & $Y_{14}$ \\
\hline$X_{1}$ Conelation Coefficient &, 246 &, $402^{28}$ &, 072 &., 180 & 1,199 \\
\hline Sig.(2-Tiled) & 099 &, 006 & .636 & .233 & .186 \\
\hline $\mathrm{N}$ & 46 & 46 & 46 & 46 & 46 \\
\hline $\bar{X}_{||}$Correlation Coefficient & $334^{8}$ &, $403^{88}$ & 1114 & 234 &., 032 \\
\hline Sig. (2.Tuled) &, 023 &, 005 &, 450 &, 117 &, 833 \\
\hline $\mathrm{N}$ & 46 & 46 & 46 & 46 & 46 \\
\hline $\bar{X}_{12}$ Correlation Coefticient & 250 &, 117 &, 022 &, 047 &, 259 \\
\hline Sig. (2-Tailed) & , 094 &, 437 & 882 &, 756 & ,082 \\
\hline $\mathrm{N}$ & 46 & 46 & 46 & 46 & 46 \\
\hline $\bar{X}_{13}$ Correlation Coefficient & 056 &, 128 & .260 & .213 & 0,042 \\
\hline Sig. (2.Taled) &, 714 &, 395 & , 08! &, 156 &, 783 \\
\hline $\mathrm{N}$ & 46 & 46 & 46 & 46 & 46 \\
\hline $\mathrm{X}_{1}$ COmelation Coefficient &, $10 !$ &, 168 &, 148 & 0,026 &., 045 \\
\hline Sig. (2.Tailed) &, 506 & 265 &, 328 & 862 &, 764 \\
\hline $\mathrm{N}$ & 46 & 46 & 46 & 46 & 46 \\
\hline $\mathrm{X}_{15}$ Comelation Coefficient &, $322^{8}$ &, $421^{18}$ &, 072 &, 180 &, 114 \\
\hline Sig. (2.Tailed) &, 029 &, 004 &, 636 &, 233 &, 453 \\
\hline $\mathrm{N}$ & 46 & 46 & 46 & 46 & 46 \\
\hline
\end{tabular}

Hasil olahan data kocelasi bubongan antara keberclayann masyarakat dan efeltivitas kemitraan

\begin{tabular}{|c|c|c|c|c|c|c|c|}
\hline & $Y_{1}$ & $Y_{11}$ & $Y_{12}$ & $y_{13}$ & $Y_{16}$ & $Y_{15}$ & $Y_{16}$ \\
\hline Y, Conelation Coefficient & $.528^{28}$ & .147 & .062 & $.327^{8}$ & $319^{8}$ & $.46^{2 x}$ & $367^{4}$ \\
\hline Sig (2.Taled) & 000 &, 328 & 683 &, 026 &, 031 &, 002 &, 012 \\
\hline $\mathrm{N}$ & 46 & 46 & 46 & 46 & 46 & 46 & 46 \\
\hline$Y_{21}$ Correlation Coefficient & $420^{18}$ & 0,075 &., $12 !$ &, $428^{48}$ & $22 !$ & $.333^{8}$ &, $338^{4}$ \\
\hline Sige (2-Tuled) &, 004 &, 620 &, 425 &, 003 &, 140 &, 024 &, 022 \\
\hline $\mathrm{N}$ & 46 & 46 & 46 & 46 & 46 & 46 & \\
\hline$Y_{22}$ Corelation Coefficient &, 145 & $347^{*}$ & 258 &, 016 &, 080 &, 189 &, 004 \\
\hline Siz (2-Tailec) & .336 & 018 & .083 & 917 & .599 & .208 & 980 \\
\hline N & 46 & 46 & 46 & 46 & 46 & 46 & 46 \\
\hline$Y_{23}$ Conelation Coefficient &, 177 & $308^{8}$ & .286 &, 083 &, 189 &, 164 & ,04! \\
\hline Siz (2.Taled $)$ & .239 &, 038 & 054 & .584 &, 207 & .277 & .788 \\
\hline$N$ & 46 & 46 & 46 & 46 & 46 & 46 & 46 \\
\hline$Y_{24}$ Conelation Coefficient &, 165 &, 075 &, $06 !$ & .087 &, 133 & 109 &, 184 \\
\hline Sig (2-Taled) & .274 &, 620 &, 685 &, 564 &, 377 & , 47! & 222 \\
\hline $\mathrm{N}$ & 46 & 46 & 46 & 46 & 46 & 46 & 46 \\
\hline
\end{tabular}


172 | Fadilah, Ratna. et. al. Analisis Kemitraan Antara Pabrik Gula Jatitujuh dengan Petani Tebu Rakyat di Majalengka, Jawa Barat 